\title{
Urban Expansion of the Largest Cities in Bosnia and Herzegovina over the Period 2000-2018
}

\author{
Branislav Drašković ${ }^{A}$ \\ Received: June 01, 2021 | Revised: October 11, 2021 | Accepted: October 13, 2021 \\ doi: 10.5937/gp25-32535
}

\begin{abstract}
The paper analyses the databases Urban Atlas (UA), Imperviousness, and CORINE Land Cover (CLC) for the largest cities in Bosnia and Herzegovina (B\&H). The UA database contains information for five functional urban zones with more than 100,000 inhabitants: Sarajevo, Banja Luka, Tuzla, Mostar, and Zenica. The Imperviousness database is related to the subclasses of the urban atlas because the impermeability percentage has been used for a more detailed classification within the discontinuous urban area. The CLC database provides insight into the intensity of expansion of these cities during three six-year periods: 2000-2006, 2006-2012, and 2012-2018. The research has been used to analyse the expansion of urban zones, the structure, and form of cities, and the impact of urban expansion on the surrounding area. The results of the research show that, despite the negative demographic trends, there is a trend of urban expansion in $\mathrm{B} \& \mathrm{H}$, mainly overthe agricultural land. According to the $\mathrm{CLC}$ database in the period 2000-2018, artificial areas increased in spatial coverage from $1.35 \%$ to $1.7 \%$, and urban fabric from $0.99 \%$ to $1.27 \%$. The Imperviousness database shows that in 2018 sealed areas covered $1.59 \%$ and built-up areas $0.8 \%$ of the territory of $B \& H$. The 2013 census showed that the number of inhabitants in all five functional urban areas decreased compared to 1991, but despite that fact, the expansion of urban zones continues with a weaker or stronger intensity.So far, there has been no research on urban development based on the high-resolution layers UA and Imperviousness database in B\&H, so that such research is the most significant contribution of this article.
\end{abstract}

Keywords: Urban Atlas; Imperviousness; CORINE LC; expansion; cities; B\&H

\section{Introduction}

Socio-economic processes in the former socialist countries in the period of transition have resulted in accelerated growth of all capital cities in Central, Eastern and South-eastern Europe. That is why many researchers have expected processes of sprawl to be observed around the cities in result of changes in the mechanisms of urban development in these countries (Slaev \& Kovačev, 2014). Post-socialist cities have gained new authority and functions since the political and fiscal decentralization shifted power and responsibilities to local governments. Substantial changes have occurred in the nature, role and functioning of government and of other institutions involved in spatial development and urban policy (Nedović-Budić et al., 2006).Urban expansion and suburbanization in South East Europe (SEE), is often fueled by rural-tourban migration of poor, rural strata, who move to the big cities in search of livelihood (Leontidou et al., 2007). These rural-to-urban migrants often settle on the urban fringe because of lower land prices (Korcelli, 1990). In many cases, economic developments and shortcomings in institutional frameworks have re-

\footnotetext{
A University of East Sarajevo, Department of Geography, East Sarajevo, Bosnia and Herzegovina; e-mail: branislav.draskovic@pof.ues.rs.ba
} 
sulted in the inefficient use of land in suburbs (Roose et al., 2013). Eastern European urbanization can best be characterised as hybrid: cities and city regions simultaneously manifest characteristics of convergent adaptation and path-dependency; they prove typical features of capitalist urbanization, but relics of the socialist past are still omnipresent (Taubenbock et al., 2019).

In the postsocialist states, the impacts of suburbanisation are only beginning to be felt at present (Hlaváček et al., 2019). Increased private (commercial or residential) construction or "post-socialist privatism" has various socio-spatial consequences visible in both the cities' altered appearance and identity as well as the quality of life in them (Nedović-Budić et al., 2006; Svirčić et al., 2019).

Researching suburbanization and urban sprawl in Belgrade and Sofia, Slaev et al. (2018) have identified several factors that are typical drivers as well as others, which are atypical. The higher rates of car ownership and incomes of certain social strata which accompanied the transition are the only local economic factors that were founded to correspond with the typical, global drivers of suburbanization and sprawl. The atypical factors, on the other hand, are attributable to drivers and conditions specific to SEE. Cultural traditions and housing preferences are probably the most important factor contributing to urban density. Grigorescu et al. (2012) in the study related to urban sprawl in Romania indicates a stronger connection with the socio-political factors over in the post-communist period as compared to the natural drivers which can be approached only as background in assessing land transformation.

Researching land cover changes in Budapest Lennert et al. (2020) summarized three "theorems": (1) Due to urban sprawl, the extent of artificial surfaces in the functional urban area will increase over time, irrespective of the economic and political system; (2) Land conversion will affect different types of agricultural, natural, and seminatural land use cover to varying degrees; and (3) The decline in agricultural, natural, and seminatural areas will not be a general phenomenon and will not cover all categories. Another important consideration is that suburbanization and sprawl can be understood as the initial phases in a greater cycle of urban enlargement. In the first phase of a cycle, suburban areas are subject to low-density growth (i.e. sprawl), but if the city continues to grow in this direction, the next phases result in an increasingly denser urban fabric (Slaev et al., 2018). Nevertheless, there are two features generally encountered when considering urban sprawl: the first one is related to the spatial discontinuity and low density of builtup areas, and the second notes usually an increase of built-up areas significantly greater than the population growth (Petrescu, 2019).

Theincreasing urban sprawl is causing land-use conflicts and is posing a major threat to sustainable land use. Therefore, there is an urgent need to assess the extent of urban sprawl in Europe in a consistent and comparable way and to provide relevant evidence that can aid the development of European policy with regard to built-up areas.

Addressing the issue, in 2009 the European Space Agency (ESA) started the Global Monitoring for Environment and Security (GMES) program releasing the Urban Atlas, a dataset on land use for all cities in Europe with a population of more than 100,000 inhabitants (Prastacos \& Chrysoulakis, 2011). The spatial unit for assessing the spatial structures of urban sprawl and suburbanization are functional urban areas (FUAs). The first UA database refers to 2006 and contains 319 FUAs. The next UA database refers to 2012, containing 785 FUAs with more than 50,000 inhabitants, including West Balkan countries. The last UA 2018 database contains a full dataset for 788 FUAs and the 2012-2018 change product (CLMS, 2020).

As the first post-war census in $\mathrm{B} \& \mathrm{H}$ was conducted in 2013, after the database in Europe had already been formed, only the cities with more than 100,000 inhabitants (according to the 1991 census) have been included in the UA database. For example, in 1991, the city of Bijeljina had about 97,000 inhabitants and was not included in the UA, although according to the 2013 census it had 107,700.Taking into account this criterion, there were five functional urban zones: Sarajevo, Banja Luka, Tuzla, Mostar, and Zenica. The criteria for defining the area covered by the FUA are not related just to the administrative boundaries of cities or to the political boundaries of the entities and cantons in $\mathrm{B} \& \mathrm{H}$, but also to the economic gravity zones and the labor market. According to EUROSTAT (2016), anFUA consists of a city and its commuting zone. FUAs, therefore, consist of a densely inhabited city and a less densely populated commuting zone whose labor market is highly integrated with the city. Thus the FUA Sarajevo, in addition to 9 municipalities belonging to the Sarajevo Canton, includes all municipalities belonging to the city of East Sarajevo (except Sokolac) and 2 municipalities of the Central Bosnia Canton (Kiseljak and Kreševo) and Zenica-Doboj Canton (Breza and Visoko). FUA Banja Luka includes the city area of Banja Luka and the municipalities of Laktaši, Čelinac, and Gradiška. The FUA Tuzla includes the city area of Tuzla and the municipalities of Živinice, Kalesija, and Lukavac. The FUA Mostar includes the city area of Mostar and the municipalities of Široki Brijeg, East Mostar, and Čitluk. The FUA Zenica includes the city area of Zenica and the municipalities of Busovača and Vitez. 
The population in FUAs ranges from 153,123 (Mostar) to 543,189 (Sarajevo), and the total area from $865.5 \mathrm{~km} 2$ (Zenica) to $2750.9 \mathrm{~km}^{2}$ (Banja Luka). The population density (population divided by total area) is 84 people $/ \mathrm{km}^{2}$ in Mostar and 219.3 people $/ \mathrm{km}^{2}$ in Tuzla. Following the depopulation trend in $\mathrm{B} \& \mathrm{H}$, the population in all five FUAs reduced between the two censuses (Table 1). In addition to negative demographic trends, the war events in $\mathrm{B} \& \mathrm{H}$ in the period 1992-1995 significantly contributed to this. Zenica has the largest decrease of $20.14 \%$ and Banja Luka the lowest one, with $5.56 \%$. the proximity of natural resources (especially mineral resources), fertile land, etc.

The aim of this paper is to determine the structure and spatial patterns of urban expansion in the largest FUAs inB\&H. Understanding the urban growth phenomenon is among the major issues that public services have to deal with. As B\&H is among the poorest countries in Europe, it is of great importance that urban development is both efficient and effective.The period 2000-2018 has beentaken for the CLC data, 20062018 for the Imperviousness data, while the data for the UA refer to the period 2012-2018.

Table 1. Area, population, and population density of FUAs

\begin{tabular}{|l|c|c|c|c|c|}
\hline \multirow{2}{*}{ FUAs } & Area & \multicolumn{2}{|c|}{ Population } & Decreasing & Pop. density 2013 \\
\cline { 2 - 6 } & $\mathbf{P}\left(\mathbf{k m}^{2}\right)$ & Census 1991 & Census 2013 & $\%$ & People/km ${ }^{2}$ \\
\hline Sarajevo & 2636.2 & 619,546 & 543,189 & -12.3 & 206.1 \\
\hline Banja Luka & 2749.0 & 304,211 & 287,283 & -5.6 & 104.5 \\
\hline Tuzla & 1123.0 & 277,004 & 246,317 & -11.1 & 219.3 \\
\hline Mostar & 1821.9 & 169,373 & 153,123 & -9.6 & 84.0 \\
\hline Zenica & 865.3 & 193,341 & 154,409 & -20.1 & 178.5 \\
\hline
\end{tabular}

According to the EEA (2016), the main drivers of urban expansion are divided into demographic, socio-economic, political, technological, and geophysical. Each FUA has its own specifics that affect faster or slower expansion. On the example of FUAs in $\mathrm{B} \& \mathrm{H}$, the demographic drivers of urbanization are not related to population growth but to internal migration in the rural-urban direction. The predominantly young population is leaving rural areas and settling in cities looking for betterliving conditions. Socio-economic driversare related to the growth of GDP, which increased by almost 4 times in B\&H in the period 2000-2018, i.e. from 5.5 billion to 20.18 billion dollars (World Bank, 2021). In this regard, the population income growth is often associated with the construction of houses and holiday homes in the urban periphery. The political drivers of urbanization are modern legislation and promotion of the planned sustainable expansion of cities, as well as possible subsidies for the construction of new houses on the outskirts of the city. The technological driver of urbanization refers to technological development emerging in the 20th and 21st centuries through the increase in the number of cars, which relativizes the distance between the place of residence and the workplace. Combined with the high cost of housing in urban centers, it makes suburban areas more attractive. The number of registered vehicles in $\mathrm{B} \& \mathrm{H}$ increased from 895,425 in 2013 to 1,175,731 in 2019 (BiHAMK, 2020). Geophysical drivers are related to the topographic limits of urban sprawl and the steep relief that makes construction difficult, and alsoto

\section{Study area}

Bosnia and Herzegovina is a country in the Western Balkans, with an area of $51.209 \mathrm{~km}^{2}$ (Figure 1). The Dayton Peace Agreement from 1995 created a new state structure consisting of the Federation of $\mathrm{B} \& \mathrm{H}$ (FB\&H) and RepublikaSrpska (RS) and since 2000 the Brčko District (BD). According to the last census from 2013, B\&H has about 3.53 million inhabitants (ASB\&H, 2016), which is a significant loss in comparison with the previous census from 1991, when it had 4.37 million inhabitants (-19.2\%). The three main ethnic groups are Bosniaks (50.1\%), Serbs (30.8\%), and Croats (15.4\%). $\mathrm{B} \& \mathrm{H}$ has one of the lowest densities of the urban population, with $49.2 \%$ of the total population living in urban areas (World Bank, 2021), comparing to the European average of $75 \%$ (Oueslati et al., 2015).

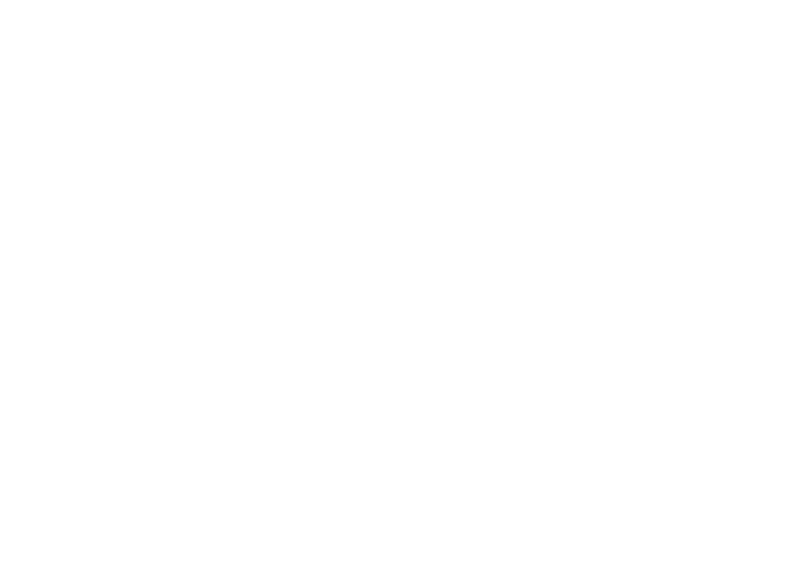

Figure 1. Location of B\&H and FUAs Basemap source: Openstreet Map [click on figure to enlarge] 
The process of depopulation in $\mathrm{B} \& \mathrm{H}$ is especially intense in the second decade of the 21st century. RS has been recording a negative population growth since 2002, and in the period 2013-2018 averaged to - 4,732 annually (RSIS, 2020). The FB\&H had a negative population growth for the first time in 2013, while losses in the period 2013-2018 averaged to - 4,580 annually (FB\&H BS, 2020). Official estimates of entity statistics agencies say that in the period 2013-2018 RS lost 23,277 and FB\&H 22,898,which makes a total of over 46,000 inhabitants. According to the FB\&H Bureau of Statistics, 24,154 citizens or 4,026 per year left $\mathrm{B} \& \mathrm{H}$ in the same period. The total demographic losses amount to almost 13,500 inhabitants per year, with a tendency for constant growth (Drašković et al., 2021). Population Situation Analysis has confirmed that $\mathrm{B} \& \mathrm{H}$ is the country with one of the lowest fertility in the world (1.25), high-level migrations and population aging as well as deeply rooted gender inequalities. By 2070, such demographic trends and inequalities will lead to a decline in total population by over $50 \%$ while demographic structure will be skewed towards the older population (with their share in the total population of over 40\%) (ASB\&H, 2020).

$\mathrm{B} \& \mathrm{H}$ is dominated by small settlements with more than $65 \%$ of urban settlements have less than 10,000 inhabitants. Due to the specificity of the relief, the population lives in a rather fragmented settlement system comprised of 6,141 settlements of uneven population density. Evident polarization in the urban system of $\mathrm{B} \& \mathrm{H}$ is reflected in the very dynamic monocentrism of the capital city and the regional centers, which is further intensified by the consequences of the war through the resettlement of a large number of refugees and displaced persons (Gekić \& BidžanGekić, 2019).Despite the general trend of depopulation, urban areas continued to expand. Two parallel socio-economic processes are dominant: urbanization and deagrarization. The population is concentrated around larger cities while rural areas are sparsely populated (Drašković et al., 2021).Although the economic development has been relatively slow, the largest cities in B\&H have maintained substantial competitive advantages compared to provincial cities and towns in attracting national and foreign capitals. That phenomenon has attracted the people who lost their jobs in the former socialist enterprises and were seeking employment.In this regard, in five Central and Eastern European countries during the post-socialist period Schmidt et al. (2014) identified that larger cities which were better connected to the political elite and more economically integrated with global investment patterns experienced more extensive urban sprawl than their smaller and mid-sized counterparts.

\section{Methods and data}

Monitoring the urban expansion and its impact on the environment in Europe takes place through various programs and services, among which the most famous are Urban Atlas, CORINE Land Cover, and Imperviousness. These services are a part of the Copernicus system, one of the most important European programs for monitoring the surface of the Earth.The changes that appear on the surface are visible on satellite images, and over the course of time they can be compared, and thus the differences and directions of spatial development can be set out.

In the context of globalization and climate change, not only the urbanization process is fast, but the consequences due to the increase of imperviousness pose serious challenges related to the indication of risks (heatwave events, floods, pollution, etc.) (Lefebvre et al., 2016). Buildings and artificial covers modify the climatic conditions (including energy budget, radiation components, and wind conditions) in cities (Marković et al., 2013). The coolest surfaces are natural covers (water, vegetation), while the hottest surfaces are concrete pavements, asphalt, and rubber paving when exposed to direct solar radiation (Dezső et al., 2019).
The UA provides pan-European comparable land cover and land use data for FUA. The UA is mainly based on the combination of (statistical) image classification and the visual interpretation of very high satellite imagery. Multispectral SPOT 5 \& 6, Formosat-2 pan-sharpened imagery with 2 to $2.5 \mathrm{~m}$ spatial resolution is used as input data. The built-up classes are combined with density information on the level of sealed soil derived from the high-resolution layers (HRLs) Imperviousness to provide more detail in the density of the urban fabric. Finally, the UA product is complemented end enriched with functional information (road network, services, utilities, etc.) using ancillary data such as local city maps or online map services (EEA, 2017b).

The land use classification system in UA identifies 20 different land use classes, 17 are 'artificial surfaces' that is, developed/built-up areas, and 3 are nondeveloped/natural areas. Six artificial surfaces classes, the 'urban fabric', describe built up/density levels, they could be therefore considered land cover rather than land-use classes. There are 5 different classes for transport infrastructure (fast transit roads, other roads, railroads, ports, and airports) and 6 classes 
for other uses (industrial/commercial/public facilities, mineral extraction/dump sites, construction areas, land without use, green urban areas and sports/ leisure facilities). The database is in vector format (Prastacos et al., 2017).

The first data from the UA for B\&H refer to 2012 and then to 2018 and the changes that occurred in the period 2012-2018. Comparing to the CLC database UAclasses are classified in more detail, so that the discontinuous urban area (CLC code 1.1.2) is divided into four subclasses, depending on the imperviousness density, from a high degree of urbanization (50\%-80\%) to a very low degree of urbanization (below $10 \%)$.

The HRL Imperviousness Density are raster-based datasets that provide information about impervious (sealed) surfaces (e.g. roads and built up areas). It consists two types of status products: Imperviousness Density (IMD), Impervious Built-up (IBU) and additional change layers. The status layers are available in $10 \mathrm{~m}$ (2018) and $20 \mathrm{~m}$ spatial resolution (20062015). The HRL Imperviousness provides a per-pixel estimate of impermeable cover of soil as an index for the degree of imperviousness (0-100\%). Imperviousness change layers were produced as a difference between the corresponding reference dates and are presented as degree of imperviousness change (IMC). Sealing has effects on various natural processes and functions, such as hydrological processes, the quasi irreversible loss of soil functions, loss of habitats and biodiversity; the sealing of soil furthermore has implications on urban climate, e.g. the urban heat island effect (CLMS, 2020).Soil sealing is one of the greatest threats to the soil and its ecosystem services and is a common syndrome of land degradation around expanding urban areas. Sealed surfaces prohibit water infiltration and cause stronger surface run-off (Tobias et al., 2018). This increases the threat of floods, the pollution of waters, and decreases the amount of subsoil water and evaporation. The data demonstrate, moreover, how artificial patches and barriers fragment landscape more and more, endangering thereby biodiversity and decreasing green surfaces (Hardi et al., 2020). Urbanization with an increase of non-permeable surfaces and lack of natural drainage created additional flooding issues that did not previously exist and that never before there had been so many human assets that were in the way of floods like today (Prokić et al., 2019).

In 1985, the CLC databases and several of its programs were taken over by the European Environment Agency (EEA) with the aim of collecting, coordinating, and ensuring the consistency of information on natural resources and the environment. The first CLC project for B\&H started in 1998 and was successfully completed in 2000. The result was the creation of the B\&H CLC 2000 database, which included the identification of the types of surface cover at the level of the main classes, and also the second and third level subclass with a detailed description of the structural characteristics. Subsequently, the CLC 2006, CLC 2012, and CLC 2018 databases were created with the aim to monitor the dynamic changes in the land cover (Drašković et al., 2020). This vector-based dataset includes 44 land cover and land use classes. In 2019, the EEA published an updatedillustrated guide to the nomenclature of land cover types with a structural classification at three hierarchical levels and a differentiated level of detail (details at: EEA, 2019).

The UA has a legend designed to capture urban land use, including low-density urban fabric, and a resolution that is 100 times higher than CLC(Figure $2-3)$. The scale of CLC is $1: 100,000$ and the minimum mapping unit is $25 \mathrm{ha}$. The scale of UA is 1:10,000 and the minimum mapping unit is 0.25 ha for the artificial surfaces and 1 ha for the other surfaces.

Several of the land use classes identified in UA account for a very small percentage of the urban area
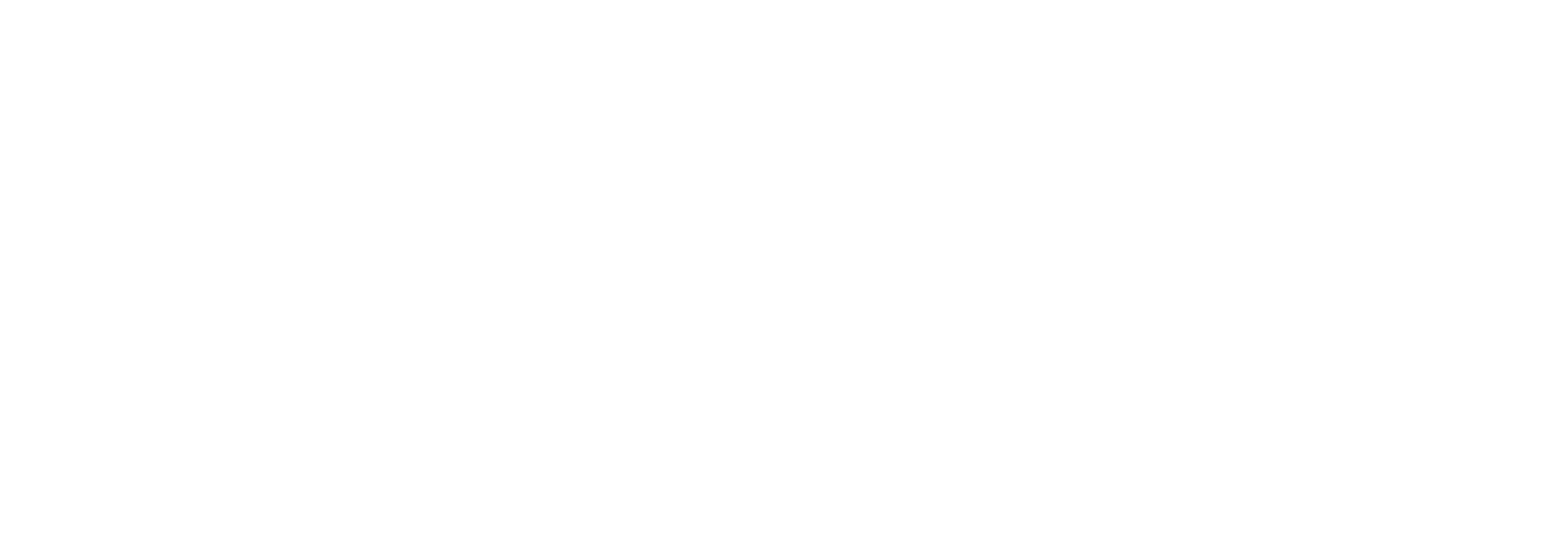

Figure 2 and 3. The difference between details level of CLC and UA dataset in Sarajevo urban area [click on figure to enlarge] 
Table 2. Land use UA reclassification

\begin{tabular}{|l|l|l|l|}
\hline Class & Name & UA Code & Sealing degree \\
\hline C1 & Continuous urban fabric areas & 11100 & $80-100 \%$ \\
\hline C2 & Discontinuous dense urban fabric & 11210 & $50-80 \%$ \\
\hline C3 & Discontinuous urban fabric & $11220,11230,11240,11300$ & $<50 \%$ \\
\hline C4 & Industrial/commercial areas & 12100 & \\
\hline C5 & Transport infrastructure & $12210,12220,12230,12300,12400$ & \\
\hline C6 & $\begin{array}{l}\text { Mine/Dump sites, Construction/ } \\
\text { Land without use }\end{array}$ & $13100,13300,13400$ & \\
\hline C7 & Green areas and sport facilities & 14100,14200 & \\
\hline C8 & Agricultural + Semi-natural areas & 20000 & \\
\hline C9 & Forest & 30000 & \\
\hline C10 & Water and wetlands & 50000 & \\
\hline
\end{tabular}

are not so relevant for this research and a detailed analysis would not provide a meaningful insight on the form of the city. The 20 UA classes were therefore reclassified into 10 classes (Table 2). Three of the 10 classes represent urban fabric areas. The CLC class 1.1.2 (Discontinuous urban fabric) has been broken down into the following sub-classes in UA: 1.2.1.1.0 (Discontinuous dense urban fabric: sealing level 50\% 80\%), 1.1.2.2.0 (Discontinuous medium density urban fabric: sealing level 30\% - 50\%), 1.1.2.3.0 (Discontinuous low density urban fabric: sealing level 10\% - 30\%), 1.1.2.4.0 (Discontinuous very low density urban fabric: sealing level $<10 \%)$ and Isolated structures (11300). Transport infrastructure (fast roads, other roads, railroads, ports, airports) were aggregated into one class and the same was done for green areas and sports facilities. For separation between Discontinuous urban fabric, HRL Imperviousness density is required.

By collecting and analyzing the satellite images from different periods, the situation on the ground can be compared and the differences and directions of spatial development can be set out. UA, IMD, and CLC changes of data for the five FUAs were extracted using GIS software in order to visualize and quantify changes. The data are exported to Microsoft Excel and classified by the type of change. By using the Sort \& Filter and Subtotal Sum tools, the individual sum of classes and changes by periods are calculated. Through the processing of this data, we get a spatial and temporal insight into all the processes that take place in the field.

\section{Results and discussion}

According to CLC 2018 artificial areas in B\&H cover $1.7 \%$ and urban fabric (in CLC nomenclature code 1.1) cover $1.27 \%$ of the territory. IMD 2018 database shows that the sealed area covers $1.59 \%$ of the territory.The differences between the two databases could be a result of different spatial resolution and classification nomenclature. Namely, IMD has a higher resolution and excludes some CLC subclasses: railway tracks not associated with other impervious surfaces (i.e. outside built-up area), dump sites, mines, quarries, peat extraction areas, construction sites without discernible evolving built-up structures,etc. Built-up areas are a sub-group of the sealed areas. The term refers to areas where above-ground building constructions can be found. IBU 2018 database for B\&H shows that build-up areas cover $0.8 \%$ and non-built ones $99.2 \%$ of the territory.The IMD is a raster displaying the degree of imperviousness (1-100\%) for the five FUAs and for the reference year 2018 in 10m spatial resolution (Figure4-8).

According to the IMD 2018 database, Sarajevo has the largest imperviousness area $\left(102.45 \mathrm{~km}^{2}\right)$ and $\mathrm{Ze}$ - nica the smallest one $\left(28.99 \mathrm{~km}^{2}\right)$. However, when the imperviousness area is shown in relation to the total area of FUA, then Tuzla is in the first place (5.7\%) and Mostar isthe last (2.07\%). According to the IBU 2018 database, Sarajevo has the largest built-up areas (53.24 $\mathrm{km}^{2}$ ) and Zenica the smallest ones $\left(13.24 \mathrm{~km}^{2}\right)$. In relation to the total area, Tuzla is again in the first place (3.89\%) while Mostar is the last (1.04\%) (Table 3).

However, the difference between IMD and IBU classes should be emphasized because IMD covers all imperviousness zones (e.g. roads and industrial zones) while IBU includes only the populated areas, which means that built-up are part of imperviousness areas. For example, the FUA Sarajevo has $3.89 \%$ of imperviousness areas of all densities, and $2.02 \%$ of built-up zones.IMD has been used in the reclassification of urban areas within the UA. Table 4 provides an overview according to the imperviousness density on the basis of which the subclasses UA 11100 (IMD> 80\%), 11210 (IMD 50-80\%), 11220 (IMD 30-50\%), 11230 (IMD 10$30 \%)$ and $11240(\mathrm{IMD}<10 \%)$ are obtained. 

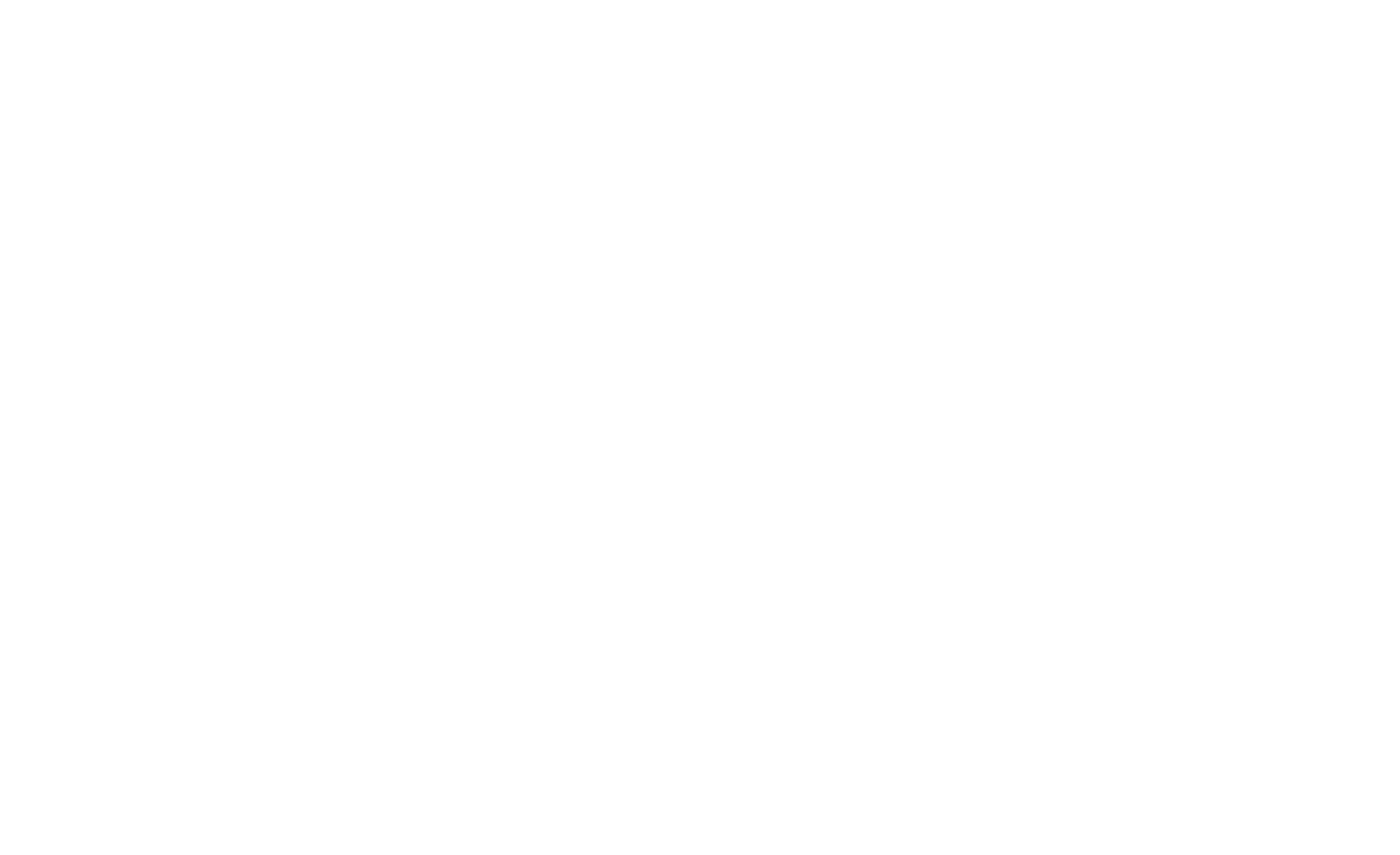

Figure4 to 8. Degree of Imperviousness and UA maps of the FUAs (the forest is shown in green, the agricultural land in yellow, and the urban areas in red) [click on figure to enlarge]

Table 3. IMD 2018 and IBU 2018 total areasfor FUAs

\begin{tabular}{|l|c|c|c|c|c|c|c|c|c|c|}
\hline \multirow{2}{*}{} & \multicolumn{2}{|c|}{ Sarajevo } & \multicolumn{2}{c|}{ Banja Luka } & \multicolumn{2}{c|}{ Tuzla } & \multicolumn{2}{c|}{ Mostar } & \multicolumn{2}{c|}{ Zenica } \\
\cline { 2 - 12 } & $\mathbf{k m}^{\mathbf{2}}$ & $\%$ & $\mathbf{k m}^{\mathbf{2}}$ & $\%$ & $\mathbf{k m}^{\mathbf{2}}$ & $\%$ & $\mathbf{k m}^{\mathbf{2}}$ & $\%$ & $\mathbf{k m}^{\mathbf{2}}$ & $\%$ \\
\hline IBU 2018 & 53.24 & 2.02 & 33.94 & 1.23 & 43.67 & 3.89 & 18.94 & 1.04 & 13.24 & 1.53 \\
\hline IMD 2018 & 102.45 & 3.89 & 65.82 & 2.39 & 64.01 & 5.70 & 37.75 & 2.07 & 28.99 & 3.35 \\
\hline
\end{tabular}

Source: own work based on IMD 2018 and IBU 2018 database

Table 4. Detailed Imperviousness densityof FUAsshown by percentages

\begin{tabular}{|l|c|c|c|c|c|c|c|c|c|c|c|}
\hline \multirow{2}{*}{ FUAs } & Area & \multicolumn{2}{|c|}{ IMD $>\mathbf{8 0} \%$} & \multicolumn{2}{|c|}{ IMD 50-80\% } & \multicolumn{2}{c|}{ IMD 30-50\% } & \multicolumn{2}{|c|}{ IMD 10-30\% } & \multicolumn{2}{c|}{ IMD<10\% } \\
\cline { 2 - 14 } & $\mathrm{km}^{2}$ & $\mathrm{~km}^{2}$ & $\%$ & $\mathrm{~km}^{2}$ & $\%$ & $\mathrm{~km}^{2}$ & $\%$ & $\mathrm{~km}^{2}$ & $\%$ & $\mathrm{~km}^{2}$ & $\%$ \\
\hline Sarajevo & 2636.2 & 14.76 & 0.56 & 28.38 & 1.08 & 30.16 & 1.14 & 25.25 & 0.96 & 3.90 & 0.15 \\
\hline Banja Luka & 2749.0 & 11.79 & 0.43 & 16.90 & 0.61 & 18.83 & 0.68 & 15.45 & 0.56 & 2.85 & 0.10 \\
\hline Tuzla & 1123.0 & 6.39 & 0.57 & 13.92 & 1.24 & 20.21 & 1.80 & 19.85 & 1.77 & 3.66 & 0.33 \\
\hline Mostar & 1821.9 & 6.05 & 0.33 & 11.63 & 0.64 & 11.14 & 0.61 & 8.06 & 0.44 & 0.57 & 0.03 \\
\hline Zenica & 865.3 & 3.54 & 0.41 & 7.10 & 0.82 & 9.14 & 1.06 & 8.04 & 0.93 & 1.18 & 0.14 \\
\hline
\end{tabular}

Source: own work based on IMD 2018 database

Based on the UA data in most cities the artificial/developed land accounts for less than $30 \%$ of total land (often just 10\%-20\%) while the remaining is classified as natural areas (agricultural, forests, etc.) (Prastakos et al., 2017). In the case of FUAs in B\&H, artificial surfaces represent $13.63 \%$ of the total area in Tuzla, which is related to the highest population density, while in other cities they account for less than $10 \%$ of the area (Table 5). The distribution of urban fabric among the three land use density classes (C1, C2, C3) differs between the cities. The continuous urban fabric is con- centrated in the core of the cities, with densities diminishing as the distance from the center increases. The continuous urban fabric and discontinuous dense urban fabric ( $\mathrm{C} 1$ and $\mathrm{C} 2)$ are the most compact in Mostar and the largest widespread segregated urban zones are in Banja Luka and Tuzla. On the other hand, the highest value of discontinuous very low, low, and medium-density urban fabric (C3, <10\%-50\%) are noticed in Tuzla and Zenica.

Table 5 shows the distribution of urban subclasses according to the UA classification nomenclature. Sa- 
rajevo has the largest continuous and dense discontinuous urban area, which is expected, given the number of inhabitants. In Zenica, these subclasses cover the smallest areas. However, when it comes to the percentage share of dense urban areas in the total urbanized area, then Mostar has the highest percentage of C1 (1.7\%) and C2 (18.1\%) and thelowestpercentage of very low urbanization density (32.7\%). Banja Luka has the lowest density of urban fabric with $46.9 \%$ of the territory with a very low urbanization density (11240). rounding agricultural areas' (EEA, 2006; EEA, 2017a). Also, urban sprawls are transition zones with indefinite borders between rural and urban areas (Karakayaci, 2016). Urban sprawl can be defined as urban development with low-density housing, both residential and commercial, segregated land-use, high level of automobile use combined with a lack of public transport, which is in high demand for land (Johnson, 2001).A systematic evaluation of the existing definitions of urban sprawl showed that most definitions have three

Table 5. Urban fabric subclasses distribution in FUAs

\begin{tabular}{|c|c|c|c|c|c|c|c|c|c|c|c|c|c|c|}
\hline \multirow{2}{*}{ FUA 2018} & \multicolumn{2}{|c|}{11100} & \multicolumn{2}{|c|}{11210} & \multicolumn{2}{|c|}{11220} & \multicolumn{2}{|c|}{11230} & \multicolumn{2}{|c|}{11240} & \multicolumn{2}{|c|}{11300} & \multicolumn{2}{|c|}{ Artificial } \\
\hline & $\mathrm{km}^{2}$ & $\%$ & $\mathrm{~km}^{2}$ & $\%$ & $\mathrm{~km}^{2}$ & $\%$ & $\mathrm{~km}^{2}$ & $\%$ & $\mathrm{~km}^{2}$ & $\%$ & $\mathrm{~km}^{2}$ & $\%$ & $\mathrm{~km}^{2}$ & $\%$ \\
\hline Sarajevo & 1.8 & 1.2 & 17.1 & 11.4 & 23.1 & 15.5 & 41.6 & 27.8 & 57.2 & 38.3 & 8.5 & 5.7 & 222.5 & 8.4 \\
\hline Banja Luka & 0.4 & 0.2 & 9.5 & 5.8 & 18.9 & 11.5 & 35.9 & 21.8 & 77.1 & 46.9 & 22.6 & 13.8 & 227.9 & 8.3 \\
\hline Tuzla & 0.5 & 0.5 & 4.6 & 4.4 & 12.2 & 11.6 & 45.8 & 43.3 & 40.8 & 38.6 & 1.7 & 1.6 & 153.1 & 13.6 \\
\hline Mostar & 0.9 & 1.7 & 9.3 & 18.1 & 9.0 & 17.6 & 10.5 & 20.5 & 16.7 & 32.7 & 4.8 & 9.4 & 92.9 & 5.1 \\
\hline Zenica & 0.4 & 0.9 & 2.8 & 6.0 & 7.7 & 16.2 & 15.0 & 31.5 & 20.1 & 42.2 & 1.6 & 3.3 & 68.6 & 7.9 \\
\hline
\end{tabular}

Source: own work based on UA 2018 database

Mostar has a dense urban core due to the old part of the city, where oriental architecture with narrow streets predominates. On the other hand, Banja Luka is a modern city, most of which was built after the devastating earthquake in 1969 , and that is why the later expansion of the city was strictly regulated by spatial plans.Among other cities, Sarajevo has relatively high values of urban density, also thanks to the oriental urban core while Tuzla and Zenica have medium density.The main factors that determined the urban development in $\mathrm{B} \& \mathrm{H}$ have been the following ones: rebuilding of infrastructures, houses, and buildings, the change of economic model from the socialist to the capitalist system, and displacement of the population from one entity or region to another.

\section{Urban sprawl}

A number of definitions of urban sprawl have been suggested in the English literature, but there is no general agreement about what defines urban sprawl (Wilson et al., 2003). EEA has described sprawl as 'the physical pattern of low-density expansion of large urban areas, under market conditions, mainly into the sur- dimensions in common (Jaeger et al., 2010): (1) the expansion of urban areas; (2) the scattering of settlement areas, that is how densely clumped or widely dispersed the buildings and patches of built-up areas are within the landscape (area-intensive growth); (3) low-density development (i.e. high land uptake per person).

Table 6 provides an overview of the basic types of land cover according to the UA nomenclature. It can be seen that in all FUAs, urban areas are increasing, and agricultural land and forests, and semi-natural areas are decreasing.

Table 7 shows that urban zones are most widespread at the expense of agricultural land. In 4 out of 5 cities, over two-thirds of the expansion take place over agricultural land in the suburban zone, which is a permanent loss of agricultural land. Thanks to geophysical characteristics, in the area of Banja Luka, as much as $88.39 \%$ of new urban areas have been built on former agricultural land. Tuzla has a similar percentage with $82.35 \%$. Both cities are located in the lowland of the Peripannonian region where agricultural land predominates. Zenica and Sarajevo, located in the Bosna River Valley, also have urban sprawl

Table 6. FUAs by main classes $\left(\mathrm{km}^{2}\right)$

\begin{tabular}{|l|c|c|c|c|c|c|c|c|c|c|}
\hline & \multicolumn{2}{|c|}{ Sarajevo } & \multicolumn{2}{c|}{ Banja Luka } & \multicolumn{2}{c|}{ Tuzla } & \multicolumn{2}{c|}{ Mostar } & \multicolumn{2}{c|}{ Zenica } \\
\hline Years & $\mathbf{2 0 1 2}$ & $\mathbf{2 0 1 8}$ & $\mathbf{2 0 1 2}$ & $\mathbf{2 0 1 8}$ & $\mathbf{2 0 1 2}$ & $\mathbf{2 0 1 8}$ & $\mathbf{2 0 1 2}$ & $\mathbf{2 0 1 8}$ & $\mathbf{2 0 1 2}$ & $\mathbf{2 0 1 8}$ \\
\hline Artificial surfaces & 216.5 & 222.5 & 224.6 & 227.9 & 151.9 & 153.1 & 89.7 & 92.9 & 67.5 & 68.6 \\
\hline Agricultural areas & 525.3 & 521.0 & 1070.1 & 1067.8 & 348.8 & 348.1 & 239.6 & 239.8 & 177.1 & 176.7 \\
\hline Forest and (semi-) natural areas & 1891.2 & 1889.4 & 1443.3 & 1441.7 & 606.2 & 605.2 & 1484.5 & 1480.7 & 617.4 & 616.8 \\
\hline Water and wetlands & 4.2 & 4.3 & 13.0 & 13.6 & 16.2 & 16.7 & 9.0 & 9.3 & 3.4 & 3.4 \\
\hline
\end{tabular}

Source: own work based on UA Change 2012-2018 database 
Table 7. Structure of urban fabric sprawl to other land cover types

\begin{tabular}{|l|c|c|c|c|c|c|c|}
\hline \multirow{2}{*}{ FUA } & \multicolumn{2}{|c|}{$\begin{array}{c}\text { Other artificial (12, 13, and } \\
\text { 14) to urban fabric }\end{array}$} & \multicolumn{2}{|c|}{$\begin{array}{c}\text { Agricultural land to urban } \\
\text { fabric }\end{array}$} & \multicolumn{2}{c|}{$\begin{array}{c}\text { Forest and semi-natural to } \\
\text { urban fabric }\end{array}$} & Total \\
\cline { 2 - 8 } & $\mathbf{k m}^{2}$ & $\%$ & $\mathbf{k m}^{2}$ & $\%$ & $\mathbf{k m}^{2}$ & $\%$ & $\mathbf{k m}^{2}$ \\
\hline Sarajevo & 0.351 & 15.85 & 1.52 & 68.65 & 0.343 & 15.49 & 2.214 \\
\hline Banja Luka & 0.030 & 1.37 & 0.395 & 88.39 & 0.022 & 4.83 & 0.447 \\
\hline Tuzla & 0.039 & 1.76 & 0.28 & 82.35 & 0.021 & 6.18 & 0.34 \\
\hline Mostar & 0.138 & 6.23 & 0.289 & 33.76 & 0.429 & 50.12 & 0.856 \\
\hline Zenica & 0.025 & 1.13 & 0.252 & 76.83 & 0.051 & 15.55 & 0.328 \\
\hline
\end{tabular}

Source: own work based on UA Change 2012-2018 database

at the expense of agricultural land with $76.83 \%$ and $68.65 \%$, respectively. In Mostar alone, this percentage is significantly lower, with $33.76 \%$, because the urban sprawl takes place mainly over the karst environment, i.e. grassland (34.81\%) and forests (15.30\%), which in total makes $50.12 \%$.

In the area of Sarajevo, $15.85 \%$ of new urban zones have been built over artificial surfaces, almost half of which (7.27\%) has been built on the locations of previously registered construction sites. East Sarajevo, a new city that has been developing rapidly in the last two decades, has a significant share in this. Urban zones have been expanded at the expense of forests $(12.74 \%)$ and semi-natural areas $(2.8 \%)$ with a total of $15.49 \%$. This is partly due to topographic limits, given that the Sarajevo valley is limited to urban expansion, so it takes place not only on agricultural land but also on other artificial areas and thanks to deforestation. After Sarajevo, the city that expanded the most was Mostar with 0.856 $\mathrm{km}^{2}$, and Zenica expanded the least with $0.328 \mathrm{~km}^{2}$.

The last column in Table 7 shows the amount of urban expansion in absolute terms. If parameters such as the area and population of the FUA are included, we will obtain coefficients that give a more realistic overview of the intensity of urban sprawl. The coefficient $\mathrm{k} 1$ shows the relationship between urban sprawl and the area of FUA $\left(\mathrm{P}_{\text {urban sprawl }} / \mathrm{P}_{\mathrm{FUA}}\right)$ and is given in $\%$. The coefficient $\mathrm{k}_{2}$ shows the amount of urban sprawl per 100,000 inhabitants $\left(\mathrm{P}_{\text {urban sprawl }} /\right.$ Population/100,000). Compared to the FUA area, Sarajevo and Mostar expand the fastest with $\mathrm{k} 1$ values of 0.84 $\%$ and $0.47 \%$, followed by Zenica with $0.38 \%$, Tuzla with $0.3 \%$, and Banja Luka with $0.16 \%$. In relation to the number of inhabitants, Mostar expand the fastest with ak2 value of 0.56 , followed by Sarajevo with 0.4 , Zenica with 0.21 , Banja Luka with 0.15 , and Tuzla with 0.12 .

Figure 9 shows the absolute and relative values $\left(\mathrm{k}_{1}\right.$ and $k_{2}$ ) of urban sprawl. Sarajevo has the largest expansion in absolute terms, which is expected given that it is the largest urban zone, with twice as many inhabitants as Banja Luka and Tuzla or three times as many as Mostar and Zenica. When it comes to the relative values of urban sprawl in relation to the number

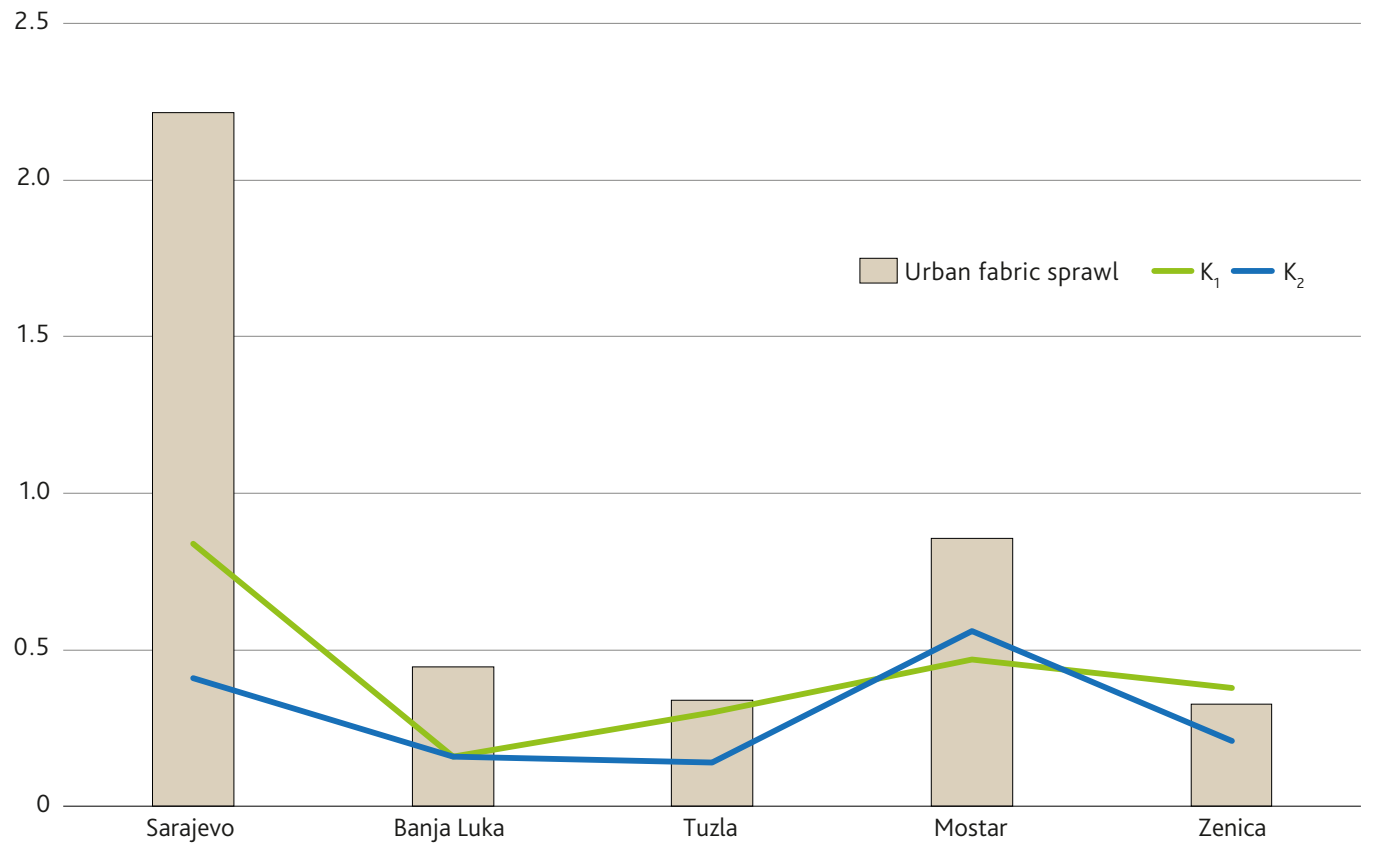

Figure 9. Absolute and relative values of urban sprawl 
of inhabitants, Mostar records the highest intensity, and Tuzla and Banja Luka the lowest one. The reasons for the rapid expansion are related to the gravitational influence of Mostar on the Herzegovina region.

Sarajevo, as a capital, attracts predominantly Bosniaks, arriving not only from Bosnia but also from the Sandžak region in Serbia and Montenegro. The data from two censuses show that the share of Bosniaks in the Sarajevo Canton population increased from $50.8 \%$ to $83.8 \%$. The city of Mostar attracts Croats $(33.9 \%$ in 1991 and $48.4 \%$ in 2013) from west Herzegovina. In the Banja Luka region, the share of Serbs in the population increased from $64.6 \%$ in 1991 to $88.6 \%$ in 2013.

According to the CLC Changes database, the urban sprawl was most intense during the period 2000-2006, when the refugee return process in $\mathrm{B} \& \mathrm{H}$ was at the largest level. New settlements were built for returnees as well as for those who wanted to stay in the new locations. The total urban sprawl in $\mathrm{B} \& \mathrm{H}$ was $62.86 \mathrm{~km}^{2}$. New settlements were built mostly at the expense of agricultural land, which was converted into a discontinuous urban area in the amount of $58.83 \mathrm{~km}^{2}$ (or 93.6\% of the total area of expansion).

The next six-year period, from 2006-2012, significantly differs from 2000-2006. Residential sprawlthe main driver of artificial development in the previous period-almost disappeared from the landscape. In the period 2006-2012, the sprawl is driven mostly by extension of mines, quarries and waste dumpsites and also by construction (EEA, 2017c). Other reasons for reducing the intensity of change include the large- ly completed refugee return process in $\mathrm{B} \& \mathrm{H}$, as well as the global economic crisis that affected the stagnation of the economy and the decline in artificial land growth (Drašković et al., 2020).

The stagnation of the urban sprawl continued in the period 2012-2018. Only $0.35 \mathrm{~km} 2$ of the new discontinuous urban area was recorded throughout the country. In this period, a trend of rapid population decline was observed. From year to year, there have been fewer and fewer newborns and more and more young people leave the country and go to developed western countries.

Thus, according to the CLC database, it is noticeable that FUAs urban sprawltook place at the expense of agricultural land mainly during the period 2000 2006. The largest expansion was in Sarajevo with $13.1 \mathrm{~km}^{2}$, followed by Tuzla with $9.28 \mathrm{~km}^{2}$ andZenica with $3.33 \mathrm{~km}^{2}$. Banja Luka and Mostar had the smallest sprawlwith $2.48 \mathrm{~km}^{2}$ and $1.69 \mathrm{~km}^{2}$ respectively. In the other two periods, there is almost no urban expansion (Figure10). The fact that small changes are not visible in the CLC database due to the low resolution occurs an additional reason for the reduced intensity of urban expansion. It is especially difficult to notice individual construction or zones of small construction sites, so urban expansion is often not registered in these cases.

Statistically significant differences show that the Urban Atlas 'sees' small and sparse features better than CORINE (Petrişor\&Petrişor, 2015).Inthe case of this research, the CLC database is partially com-

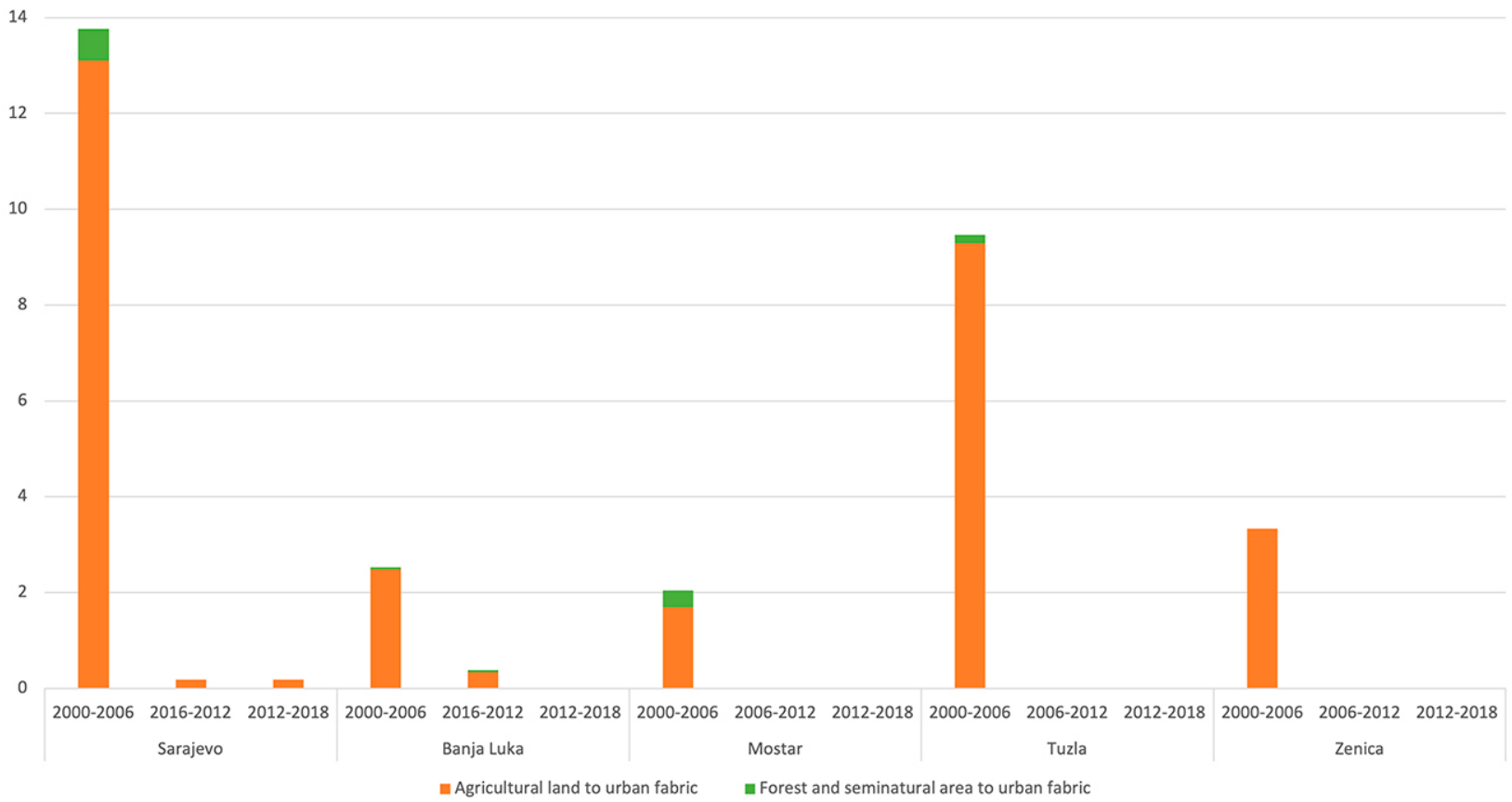

Figure 10. Urban sprawl over other classes according to CLC Changes database $\left(\mathrm{km}^{2}\right)$ 
patible with the UA database. Namely, these two databases overlap only in the period 2012-2018 when, according to the CLC database, no urban expansion was recorded in any FUA. On the other hand, higher UA resolution recorded the spread given in Tables 6 and 7, which was not registered by the CLC database.

The rapid growth and uncontrolled development of municipalities can make the development of a given settlement unsustainable; spatial conflicts can arise, the functions of individual plots may be in conflict, and the costs of transport and technical infrastructure may be unsustainable (Pach, 2016). The process of maintaining sustainable urban development requires greater regulation of local governments and stricter planning. There are numerousenvironmental risks limiting the extensive growth of settlements.A serious issue is the insufficient capacity of technical infrastructure such as sewerage and wastewater treatment.

\section{Conclusion}

According to the Urban Atlas database, the largest functional urban areas in $\mathrm{B} \& \mathrm{H}$ continue to expand despite the declining population. The urban sprawl has taken place mainly at the expense of agricultural land. Sarajevo, as the capital, represents the largest urban zone with the fastest expansion. During the period 2012-2018, it expanded to a new area of $2.214 \mathrm{~km}^{2}$, which is more than all four other FUAs combined. This trend is also a characteristic of other countries in the region. The reasons for this process could be found in rural-to-urban migrations, the higher income andnumber of motor vehicles, cultural traditions, and housing preferences, etc.The similarity between $\mathrm{B} \& \mathrm{H}$ and neighboringpost-communist countries refers to the process of transition from one economic system to another, relatively slow economic development, infrastructure construction, etc. The biggest differences relate to internal migration based on the process of post-war ethnic homogenization and thelack of employment opportunities in smaller cities.

Tuzla and Sarajevo have the highest population density, the highest percentage of areas over $50 \%$ of imperviousness density, and the most built-up areas with $3.89 \%$ and $2.2 \%$, respectively. According to the structure and distribution of urban zones, the city of Mostar has the densest urban core thanks to its oriental architecture with compact buildings and nar- row streets. In addition, after Sarajevo, Mostar has the fastest expansion in relation to the area its FUA occupies. On the other hand, Banja Luka has a low density of the city center, i.e. the urban area is spread over a large area with more than half of it with very low density, below 10\%. Also, Banja Luka has the slowest expansion compared to other FUAs. In relation to the number of inhabitants, Mostar has the highest intensity of expansion, followed by Sarajevo, while Banja Luka and Tuzla have the slowest expansion.

The CLC database shows that the highest intensity of urbanization was in the period 2000-2006. In the following two periods, the expansion of urban zones almost disappeared. However, it should be noted that the CLC database has a 100 times lower resolution compared to UA, so it is more difficult to register small changes in the urban sprawl.

Having in mind the demographic forecast, the number of inhabitants in $\mathrm{B} \& \mathrm{H}$ will further decrease, so that the urbanization will be slower. Only an accelerated economic development can be the driver that will maintain the current intensity of urbanization. It is an opportunity to focus more on better solutions in the process of urban planning.It is necessary to balance the urban expansion in order to prevail the socalled 'over-domination' of the centre,taking the environmental issues into account as well.

\section{References}

Agency for statistic of Bosnia and Herzegovina ASB\&H. (2020). Population Projections 2020-2070. http://www.bhas.ba/News/Read/42?lang=en

Agency for statistic of Bosnia and HerzegovinaASB\&H. (2016). Census of Population, Households and Dwellings in Bosnia and Herzegovina, 2013, 1991. Sarajevo. https://www.popis.gov.ba/ popis2013/doc/RezultatiPopisa SR.pdfhttp://www. statistika.ba/

BIHAMK (Bosanskohercegovački auto-moto klub/ Bosnia and Herzegovina Automobile and Motor- cycle Club) (2020). Informacija o registrovanimdrumskimvozilima u $\mathrm{BiH}$ u periodujanuar-decembar 2019 [Information on registered road vehicles in B\&H in the period January-December 2019] (in Serbian/Croatian/Bosnian) https://bihamk.ba/assets/upload/Broj registrovanih motornih vozi. pdf

Copernicus Land Monitoring Services - CLMS. (2020). Urban Atlas Mapping Guide v6.1, https:// land.copernicus.eu/user-corner/technical-library/ urban-atlas-mapping-guide 
Copernicus Land Monitoring Services- CLMS. CLC and CHA database,https://land.copernicus.eu/ pan-european

Copernicus Land Monitoring Service- CLMS. Urban Atlas, database. https://land.copernicus.eu/local/ urban-atlas

Copernicus Land Monitoring Services- CLMS. Imperviousness, database. https://land.copernicus.eu/paneuropean/high-resolution-layers/imperviousness

Dezső, Z., Pongrácz, R., \& Bartholy, J. (2019). Analysis of surface temperature measurements over complex urban sites. Geographica Pannonica, 23(4), 337-346. DOI: 10.5937/gp23-23844

Drašković, B., Berjan, S., Milić, V., Govedarica, B.,\& Radosavac, A. (2021). Structure of agricultural land losses in Bosnia and Herzegovina, Agriculture and Forestry, 67(1), 91-101. DOI: 10.17707/AgricultForest.67.1.08

Drašković, B., Ponosov, A., Zhernakova, N., Gutalj, M., \& Miletić, B. (2020). Land cover types and changes in land use in Republic of Srpska (Bosnia and Herzegovina) over the period 2000-2018. Journal of the Geographical Institute "Jovan Cvijić" SASA, 70(1), 81-88. https://doi.org/10.2298/IJGI2001081D

European Environment Agency- EEA. (2019). CORINE Land Cover Nomenclature Guidelines, https://land. copernicus.eu/user-corner/technical-library/corineland-cover-nomenclature-guidelines/html

European Environment Agency- EEA. (2017a). Ur ban sprawl in Europe, Joint EEA-FOEN report, No 11/2016. https://www.eea.europa.eu/publications/ urban-sprawl-in-europe

European Environment Agency- EEA. (2017b). CLMS Local Component: Urban Atlas, https://land.copernicus.eu/user-corner/publications/ua-flyer/view

European Environment Agency- EEA. (2017c). Bosnia and Herzegovina land cover country fact sheet 2012. https://www.eea.europa.eu/themes/landuse/ land-cover-country-fact-sheets/ba-bosnia-andherzegovinalandcover-2012.pdf/view

European Environment Agency -EEA. (2006). Urban sprawl in Europe - The ignored challenge. EEA Report 2006 No 10/2006 Luxembourg: Office for Official Publications of the European Communities. https://www.eea.europa.eu/publications/eea report 2006 10/eea report 10 2006.pdf

EUROSTAT (2016). Urban Europe - Statistics on cities, towns and suburbs. Eurostat statistical books. Luxembourg: EU.https://ec.europa.eu/eurostat/ web/products-statistical-books/-/KS-01-16-691

Federation of Bosnia \&Herzegovina Bureau of Statistics - FB\&H BS. (2020). Thematic bulletins - population and register, Statistical Database. Sarajevo. http://fzs.ba/index.php/publikacije/godisnji-bilteni/stanovnistvo-i-registar/
Gekić, H., \& Bidžan-Gekić, A. (2019). Urban hierarchyinside a divided urban system of Bosnia and Herzegovina. 1st Istanbul International Geography Congress Proceedings Book, 492-510. https://doi. org/10.26650/PB/PS12.2019.002.048

Grigorescu, I., Mitrică, B., Kucsicsa, G., Popovici, E-A., Dumitraşcu, M. \& Cuculici, R. (2012). Postcommunist land use changes related to urban sprawl in the Romanian metropolitan areas, $H U$ MAN GEOGRAPHIES - Journal of Studies and Research in Human Geography, 6(1), 35-46. http:// dx.doi.org/10.5719/hgeo.2012.61.35

Hardi, T., Repaská, G., Veselovský, J., \& Vilinová, K. (2020). Environmental Consequences of the Urban Sprawl in the Suburban Zone of Nitra. An Analysis Based on Landcover Data. Geographica Pannonica, 24(3), 205-220. doi: 10.5937/gp24-25543

Hlaváček, P., Kopáček, M. \& Horáčková, L. (2019). Impact of Suburbanisation on Sustainable Development of Settlements in Suburban Spaces: Smart and New Solutions, Sustainability, 11(24), 7182. doi:10.3390/su11247182

Jaeger, J.A.G., Bertiller, R., Schwick, C., \& Kienast, F. (2010). Suitability criteria for measures of urban sprawl, Ecological Indicators, 10(2), 427-441. (DOI: 10.1016/j.ecolind.2009.07.007).

Johnson, M.P. (2001). Environmental impacts of urban sprawl: A survey of the literature and proposed research agenda. Environment and Planning $\mathrm{A}$, 33(4), 717-735.

Karakayaci, Z. (2016). The concept of urban sprawl and its causes, The Journal of International Social Research, 9(45), 815-818.

Korcelli, P. (1990). Migration and residential mobility in the Warsaw region. Residential mobility from Poland to the Netherlands. KNAG: Utrecht, Amsterdam. pp. 46-58.

Lennert, J., Farkas, J.Z., Kovács, A.D., Molnár, A., Módos, R., Baka, D., \& Kovács Z. (2020). Measuring and Predicting Long-Term Land Cover Changes in the Functional Urban Area of Budapest, Sustainability, 12(8), 3331. https://doi.org/10.3390/ su12083331

Leontidou, L., Afouxenidis, A., Kourliouros, E., \& Marmaras, E. (2007). Infrastructure-related urban sprawl: Mega-events and hybrid peri-urban landscapes in Southern Europe. Urban sprawl in Europe: Landscapes, land-use change and policy, 69-101.

Lefebvre, A., Sannier, C., \& Corpetti, T. (2016). Monitoring Urban Areas with Sentinel-2A Data:Application to the Update of the Copernicus High Resolution Layer Imperviousness Degree, $R e$ mote Sensing, 8, 606. doi:10.3390/rs8070606

Marković, V., Savić, S., Arsenović, D., Stankov, U., \& Dolinaj, D. (2013). Quantification of artificial sur- 
faces impact on Urban Heat Island of Novi Sad (Vojvodina, Serbia). Geographica Pannonica, 17(3), 69-73. DOI: 10.5937/GeoPan1303069M

Nedović-Budić, Z., Tsenkova, S. \& Marcuse, P. (Eds.) (2006). The Urban Mosaic of Post-socialist Europe. Space, Institutions and Policy. Heidelberg: PhysicaVerlag. pp. 3-20. http://dx.doi.org/10.1007/3-79081727-9 1

Oueslati, W., Alvanides, S., \& Garrod, G. (2015). Determinants of urban sprawl in European cities. Urban Studies, 52(9), 1594-1614. doi:10.1177/0042098015577773

Pach, P. (2016). Spatial development of localities near large cities in Poland on the example of suburban area of Wroclaw. In Proceedings of the Political Sciences and Law, 3rd International Multidisciplinary Scientific Conference on Social Sciences and Arts SGEM2016, Sofia, Bulgaria, pp. 647-654. DOI: 10.5593/SGEMSOCIAL2016/HB42/S07.081

Petrescu, F. (2019). Urban sprawl from urban atlas data: Romanian case study. Management research and practice, 11(2). https://www.proquest.com/ openview/a4fb12edca21c42975377d45c0094267/1? pq-origsite $=$ gscholar $\& \mathrm{cbl}=1036417$

Petrişor, A-I., \& Petrişor, L.E. (2015). Assessing microscale environmental changes: CORINE VS the Urban Atlas. De Gruyte Open, 9(2). DOI 10.1515/pesd2015-0027

Prastacos, P., Lagarias, A., \& Chrysoulakis, N. (2017). Using the Urban Atlas dataset for estimating spatial metrics. Methodology and application in urban areas of Greece, Cybergeo. European Journal of Geography, 815. https://doi.org/10.4000/cybergeo.28051

Prastacos, P., \& Chrysoulakis, N. (2011).Urban Atlas, land use modelling and spatial metric techniques, ERSA conference papers ersallp1406, European Regional Science Association. https://core.ac.uk/ download/pdf/6580393.pdf

Prokić M., Savić S., \& Pavić D. (2019). Pluvial flooding in urban areas across the European continent. Geographica Pannonica, 23(4), 216-232. DOI: 10.5937/ gp23-23508

Republika Srpska Institute of Statistics - RSIS. (2020). Statistical Yearbook, Demographic statistics. Banja
Luka. https://www.rzs.rs.ba/static/uploads/bilteni/ stanovnistvo/BiltenDemografskaStatistika 2020 WEB.pdf

Roose, A., Kull, A., Gauk, M., \& Tali, T. (2013). Land use policy shocks in the post-communist urban fringe: A casestudy of Estonia. Land Use Policy, 30, 76-83. https://doi.org/10.1016/j.landusepol.2012.02.008

Schmidt, S., Fina, S. \& Siedentop, S. (2015). Post-socialist Sprawl: A Cross-CountryComparison, European Planning Studies, 23(7), 1357-1380. DOI: 10.1080/09654313.2014.933178

Slaev, A.D., Nedović-Budić, Z., Krunić, N., Petrić, J., \& Daskalova, D. (2018). Suburbanization and sprawl in post-socialist Belgrade and Sofia, European Planning Studies, 26(7), 1389-1412. https://doi.or $\mathrm{g} / 10.1080 / 09654313.2018 .1465530$

Slaev, A. \& Kovačev, A. (2014). Specific Issues of Urban Sprawl in Bulgaria. European Spatial Research and Policy, 21(2), 155-169. http://dx.doi.org/10.1515/ esrp-2015-0010

Svirčić Gotovac, A., \& Kerbler, B. (2019). From PostSocialist to Sustainable: The City of Ljubljana, Sustainability, 11(24), 7126. https://doi.org/10.3390/ su11247126

Taubenbok, H., Gerten, C., Rusche, K., \& Siedentop, S. (2019). Patterns of Eastern European urbanisation in the mirror of Western trends - Convergent, unique or hybrid?. Urban Analytics and City Science, 46(7), 1206-1225. https://doi. org/10.1177\%2F2399808319846902

Tobias, S., Conen, F., Duss, A., Wenzel, L.M., Buser, C., \& Alewell, C. (2018). Soil sealing and unsealing: State of the art and examples. Land Degradation and Development, 29(6), 2015-2024. https://doi. org/10.1002/ldr.2919

Wilson, E.H., Hurd, J.D., Civco, D.L., Prisloe, M.P., \& Arnold, C. (2003). Development of a geospatial model to quantify, describe and map urban growth. Remote Sensing of Environment, 86 (3), 275-285.

World Bank (2021). GDP - Bosnia and Herzegovina, World Bank national accounts data, and OECD National Accounts data files.https://data.worldbank. org/indicator/NY.GDP.MKTP.CD?locations=BA 